\title{
Preovulatory biosynthesis and granulosa cell secretion of immunoreactive oxytocin by goat ovaries*
}

\author{
D. J. Kiehm $\dagger$, D. L. Walters, S. A. J. Daniel and D. T. Armstrong \\ Departments of Physiology and Obstetrics and Gynaecology, The University of Western Ontario, \\ London, Ontario, Canada N6A 5 A5
}

\begin{abstract}
Summary. Oestrous cycles of goats were synchronized hormonally. Immunoreactive oxytocin was undetectable $(<0.1 \mathrm{ng} / \mathrm{mg}$ protein) in media from granulosa cells isolated before the LH surge for small $(1-2 \mathrm{~mm})$, medium $(3-5 \mathrm{~mm})$ and large $(>5 \mathrm{~mm}$ diameter) follicles when cultured for $24 \mathrm{~h}$ without or with added hormones. Granulosa cells from large and medium, but not small, follicles isolated 6-12 h after spontaneous preovulatory LH surges secreted high concentrations of oxytocin (4-12 $\mathrm{ng} / \mathrm{mg}$ protein). Addition of PGE-2 $(1 \mu \mathrm{g} / \mathrm{ml})$ caused a further significant $(P<0.05)$ increase in oxytocin secretion by cultured granulosa cells, whereas PGF-2 $\alpha$, FSH and LH were ineffective when added to culture media.

Ovarian venous blood and granulosa cells were collected at $0,6,12$ or $18 \mathrm{~h}$ after GnRH injection in hormonally synchronized goats. Peripheral serum LH values were increased significantly in all but 2 of 22 goats within $2 \mathrm{~h}$ of GnRH injection. At the earliest sampling time after GnRH $(6 \mathrm{~h})$, ovarian venous levels of oxytocin were increased significantly from basal levels of $0.4 \mathrm{pg} / \mathrm{ml}$ to $2.4 \mathrm{pg} / \mathrm{ml}$. Oxytocin concentrations in follicular fluid increased from a basal value of $67 \mathrm{pg} / \mathrm{ml}$ to $155 \mathrm{pg} / \mathrm{ml}$ by $6 \mathrm{~h}$ and to $372 \mathrm{pg} / \mathrm{ml}$ by $18 \mathrm{~h}$ after $\mathrm{GnRH}$ injection. Oxytocin secretion by cultured granulosa cells was not increased significantly by $6 \mathrm{~h}(0.1 \mathrm{ng} / \mathrm{mg}$ protein) but rose to 1.4 and $3.5 \mathrm{ng} / \mathrm{mg}$ protein at 12 and $18 \mathrm{~h}$, respectively. Approximately parallel increases occurred in progesterone in ovarian venous blood and granulosa cell culture media over the same time period. Oestradiol secretion by granulosa cells cultured with androstenedione as an aromatizable substrate was essentially unchanged when obtained from 0 to $12 \mathrm{~h}$ after $\mathrm{GnRH}$ injection ( $31-37 \mathrm{ng} / \mathrm{mg}$ protein), but fell significantly to $7 \cdot 4 \mathrm{ng} / \mathrm{mg}$ in cells obtained $18 \mathrm{~h}$ after GnRH injection, indicative of decreasing aromatase activity as luteinization progresses during the preovulatory period. It is concluded that granulosa cells, in response to the preovulatory LH surge, acquire the ability to synthesize and secrete oxytocin in parallel with the increased progesterone and decreased oestradiol secretion which occurs during luteinization.
\end{abstract}

Keywords: oxytocin; granulosa cells; goat; LH; luteinization

\section{Introduction}

The observation of milk ejection in a lactating goat following administration of a corpus luteum extract reported by Ott \& Scott (1910a, b) provided the first indication that the corpus luteum contained oxytocin-like activity. A possible functional role of oxytocin in corpus luteum regulation

*Reprint requests to Dr D. T. Armstrong.

†Present address: University of Cincinnati College of Medicine, Department of Obstetrics and Gynecology, Cincinnati, Ohio 45267-0526, USA. 
was suggested by the observation of Armstrong \& Hansel (1959) that exogenous oxytocin administration to cows at the beginning of the oestrous cycle shortened the cycle by causing premature luteal regression. More recently, Cooke \& Knifton (1981) demonstrated that exogenous oxytocin is also luteolytic in the goat. There has been a resurgence of interest in the possible role of oxytocin in corpus luteum function, following the reports of oxytocin in the corpus luteum of ruminant species (Wathes \& Swann, 1982; Sheldrick \& Flint, 1983). Several studies have since demonstrated that the corpus luteum is a major secretory source of this peptide during the luteal phase of the oestrous cycle in ruminants (Flint \& Sheldrick, 1983; Sheldrick \& Flint, 1983, 1984; Walters et al., 1984).

The cellular source of oxytocin in the sheep corpus luteum has been investigated by Rodgers $e t$ al. (1983) who showed that it was the large luteal cells, rather than the small luteal cells, which were responsible for secretion of this peptide. Since large luteal cells are apparently derived from granulosa cells (Alila \& Hansel, 1984), resulting from luteinization in response to the preovulatory luteinizing hormone ( $\mathrm{LH})$ surge, it has been of interest to investigate oxytocin biosynthesis and secretion by granulosa cells in advance of corpus luteum formation. Granulosa cells isolated from bovine follicles following ovary collection during various phases of the oestrous cycle exhibit a time-dependent accumulation of oxytocin in culture media (Schams et al., 1985; Geenen et al., 1985). Immunocytochemical localization of oxytocin in granulosa cells of cow antral follicles (Kruip et al., 1985) and sheep preovulatory follicles (Wathes et al., 1986) provides evidence for the presence of oxytocin in this cell type before corpus luteum formation. Cyclic increases in oxytocin mRNA in late follicular- to early luteal-phase ovarian tissue extracts at the time of ovulation, in contrast to steady state mRNA levels measured in hypothalamic tissue extracts reported by Ivell et al. (1985), support the interpretation that biosynthesis and regulatory control of oxytocin production occurs in the ovulatory follicle of the ovary (Wathes, 1984; Jungclas \& Luck, 1986). It was of interest to determine whether onset of oxytocin biosynthesis and secretion could be demonstrated in granulosa cells of preovulatory follicles at precise intervals before ovulation and whether oxytocin secretion by the granulosa cells was under gonadotrophic control. Therefore, we examined the ability of granulosa cells, isolated from follicles of the goat ovary before and after the preovulatory LH surge, to secrete oxytocin when cultured in the absence or presence of gonadotrophins and certain other hormones.

\section{Materials and Methods}

Animals and experimental procedures. Experiment I, conducted when goats were anoestrous (April-June, northern hemisphere), consisted of a preliminary experiment followed by the main experiment conducted in two replicates, using a total of 42 goats. Oestrus was induced with progestagen-impregnated sponges and pregnant mares' serum gonadotrophin (PMSG) (Equinex: Ayerst, Montreal, Quebec, Canada). Intravaginal sponge pessaries containing a synthetic progestagen ( $6 \alpha$-methyl-17 $\alpha$-acetoxy progesterone, $60 \mathrm{mg}$; Repromap: Upjohn, Kalamazoo, MI, USA) were inserted and left for 14 days. An i.m. injection of a non-superovulatory dose of PMSG (400 i.u.), was administered at the time of sponge removal. Females were allotted randomly to one of two groups at sponge removal; in Group 1 both ovaries were removed (via mid-ventral laparotomy) $24 \mathrm{~h}$ after sponge removal and in Group 2 both ovaries were removed $42 \mathrm{~h}$ after sponge removal. Ovaries were removed at the above times to ensure that they would be obtained before (Group 1) or after (Group 2) the preovulatory LH surge which normally occurs between 32 and $40 \mathrm{~h}$ after sponge removal (Armstrong et al., 1983a). For the main experiment, performed in two replicates, follicles were isolated from each pair of ovaries and pooled according to diameter as follows: small, $1-2 \mathrm{~mm}$; medium, 3-5 mm and large, $>5 \mathrm{~mm}$. Only the large follicles were utilized in the preliminary experiment. Granulosa cells were prepared and cultured in Eagle's Minimum Essential Medium (MEM) in multi-well tissue culture plates (Falcon, Falcon Plastics, Los Angeles, CA, USA) using a method described previously for pig granulosa cells (Lischinsky \& Armstrong, 1983). Individual culture wells each contained one-half follicle equivalent of granulosa cells in $1 \mathrm{ml} \mathrm{MEM}$. Cell preparations were cultured for $24 \mathrm{~h}$ at $37^{\circ} \mathrm{C}$ in an atmosphere of $5 \% \mathrm{CO}_{2}$ in air. Hormones were added to the medium as follows: control (no hormones), $0.1 \mu \mathrm{g}$ follicle-stimulating hormone (FSH) (NIH-FSH-S14), $1 \mu \mathrm{g}$ LH (NIH-LH-B8), $1 \mu \mathrm{g}$ prostaglandin (PG) E-2, and $1 \mu \mathrm{g}$ PGF- $2 \alpha$ (preliminary experiment only).

Experiment II was conducted late in the breeding season (February-March), in 3 replicates using a total of 30 goats. Vaginal progestagen sponges were used to synchronize oestrus, as in Exp. 1. A superovulatory regimen of FSH (FSH-P, Schering, Omaha, NE, USA) injections (i.m.) was given twice daily (12 h apart) for 4 days (total of 7 injections) beginning $48 \mathrm{~h}$ before sponge removal. FSH was administered as a constant dosage regimen (1.5 mg and 
$1.25 \mathrm{mg} /$ injection for large ( $45-55 \mathrm{~kg}$ ) and small ( $30-40 \mathrm{~kg}$ ) goats, respectively) except for the first injection which was 3.0 and $2.5 \mathrm{mg}$, respectively. The PGF- $2 \alpha$ analogue, cloprostenol (Estrumate: ICI, Macclesfield, Cheshire, UK) $(50 \mu \mathrm{g}$, i.m.), was given at the time of sponge removal to ensure regression of any existing corpora lutea, and the gonadotrophin-releasing analogue (GnRH-a), des-gly ${ }^{10}$, [D-Ala ${ }^{6}$ ]-LHRH ethylamide (Sigma, St Louis, MO, USA) $(50 \mu \mathrm{g}, \mathrm{i} . \mathrm{m}$.) was injected $30 \mathrm{~h}$ later. Females were allotted randomly to 1 of 4 groups (7-8 animals/group) for ovariectomy at 4 times in relation to GnRH as follows: Group 1, immediately before GnRH ( $30 \mathrm{~h}$ after sponge removal); Group 2, $6 \mathrm{~h}$ after GnRH; Group 3, $12 \mathrm{~h}$ after GnRH; and Group 4, $18 \mathrm{~h}$ after GnRH injection. Blood samples were collected from animals in Groups 2, 3 and 4 via jugular venepuncture at hourly intervals for $4 \mathrm{~h}$ beginning $30 \mathrm{~h}$ after sponge removal for LH determinations. Additional blood samples were collected from the ovarian vein and jugular vein of animals in all groups at the time of ovariectomy, for oxytocin and progesterone determinations. Blood was collected in heparinized tubes, and the plasma was harvested immediately and stored at $-20^{\circ} \mathrm{C}$ for a maximum of $8-10$ weeks until the time of hormone analyses.

Ovaries removed surgically by mid-ventral laparotomy under halothane anaesthesia were placed in MEM and kept chilled on ice until follicle dissections which were completed within $1 \mathrm{~h}$ of ovariectomy. Follicles $>4 \mathrm{~mm}$ in diameter were isolated from each pair of ovaries and granulosa cells were obtained and cultured as in Exp. I, except that follicles were pooled within animal but not between animals. Individual culture dishes each contained one-half follicle equivalent of granulosa cells in $1 \mathrm{ml}$ MEM and all preparations were cultured for $24 \mathrm{~h}$ at $37^{\circ} \mathrm{C}$ in an atmosphere of $5 \% \mathrm{CO}_{2}$ in air, in the absence or presence of LH (NIH-LH-B8) or FSH (NIH-FSH-S 14), and with or without androstenedione (Sigma) $(0.5 \mu \mathrm{M})$. At the end of the culture period medium was harvested, split into aliquots for hormone assays and stored at $-20^{\circ} \mathrm{C}$.

Hormone measurements. Progesterone was assayed in blood plasma samples (peripheral and ovarian venous) after extraction with diethyl ether, using the radioimmunoassay (RIA) method described previously (Leung \& Armstrong, 1979).

Progesterone and oestradiol were measured in cell-free media from granulosa cell cultures, without extraction, using RIA procedures described previously (Leung \& Armstrong, 1979; Daniel \& Armstrong, 1984, respectively). Assay sensitivity and intra-assay coefficient of variation for single assays for progesterone were $0.01 \mathrm{ng} / \mathrm{ml}$ and $2.52 \%$ respectively, and for oestradiol- $17 \beta$ were $50 \mathrm{pg} / \mathrm{ml}$ and $0-98 \%$, respectively. Level of cross-reactivity of the progesterone antibody for $\mathrm{C}_{21}$-metabolites of progesterone ranged from $2 \%$ for $20 a$-hydroxy-pregn-4-en-3-one to $9 \%$ for $5 \alpha$-pregnan-3,20-dione; all other steroids tested had cross-reactivities of $<1 \%$. Oestrone cross-reacted with the oestradiol-17\% antibody at a level of $3 \%$, whereas all other steroids tested exhibited cross-reactivities of $<1 \%$ (including androstenedione, which cross-reacted $<0.01 \%$ ). Plasma extraction recoveries for $\left[{ }^{3} \mathrm{H}\right]$ progesterone were $80 \%$.

LH concentrations in jugular vein blood samples were measured, when appropriate, using the antisera and methodology described by Niswender et al. (1969), and validated previously for goat serum (Armstrong et al., 1983a). Assay sensitivity and intra-assay coefficient of variation for a single assay for $\mathrm{LH}$ were $54 \cdot 0 \mathrm{pg} / \mathrm{ml}$ and $30 \cdot 24 \%$, respectively.

Oxytocin was measured in jugular and ovarian venous plasma, and in unextracted culture media, using procedures described by Schams (1983). Assay sensitivity and intra-assay coefficient of variation for a single assay were respectively $0.1 \mathrm{pg} / \mathrm{ml}$ and $0.743 \%$ for culture medium and $0.08 \mathrm{pg} / \mathrm{ml}$ and $3.04 \%$ for plasma. Low levels of cross-reactivity of oxytocin antibody with 8-lys vasopressin (1\%), and 8-arg-vasopressin (1\%) were observed (Schams et al., 1979). Oxytocin extraction recovery for unlabelled oxytocin was $70 \%$.

Protein content in granulosa cell cultures was measured by the method of Lowry et al. (1951) on total cells in each culture well following harvest of media, and hormone production during 24-h cultures was expressed per mg granulosa cell protein.

Statistical analysis. Data were analysed by one-way analysis of variance and Duncan's new multiple range test (Steel \& Torrie, 1960). Statistical significance was inferred at $P<0.05$.

\section{Results}

\section{Hormone production by granulosa cells from PMSG-treated goats}

Oxytocin. In the preliminary trial of Exp. I, involving granulosa cells from large $(>5 \mathrm{~mm}$ diameter) follicles from a total of 12 goats, oxytocin production was undetectable in culture media of cells obtained $24 \mathrm{~h}$ after progestagen sponge withdrawal (Group 1), i.e. before the expected time of the LH surge. Granulosa cells isolated $42 \mathrm{~h}$ after sponge withdrawal (Group 2) produced significant amounts of immunoreactive oxytocin. Mean oxytocin concentrations in 24-h cultures of $3.4 \pm 0.2 \mathrm{ng} / \mathrm{mg}$ protein were observed in the absence of added hormone. Oxytocin production in cells cultured with FSH $(3.6 \pm 0.2 \mathrm{ng} / \mathrm{mg})$ or PGF- $2 \alpha(4.0 \pm 0.3 \mathrm{ng} / \mathrm{mg})$ did not differ significantly from values for control cultures, whereas cells cultured with PGE-2 exhibited a small, but statistically significant $(P<0.05)$, increase in oxytocin synthesis, of $5.6 \pm 0.3 \mathrm{ng} / \mathrm{mg}$. 
The production of oxytocin by granulosa cells from each treatment group in the main experiment is shown in Table 1 . Oxytocin production was undetectable $(<0.1 \mathrm{ng} / \mathrm{mg}$ protein $/ 24 \mathrm{~h})$ in cultured cells from follicles of all sizes isolated from Group 1 animals and in cells from small follicles isolated from Group 2 goats. High concentrations of oxytocin were observed in cultures of granulosa cells from medium and large follicles, mean concentrations being higher $(P<0.05)$ in replicate 2 than in replicate 1 . Granulosa cells of medium-sized follicles secreted more $(P<0.05)$ oxytocin than did granulosa cells of large follicles within replicate (Table 1). As before, PGE-2 caused an increase $(P<0.05)$ in oxytocin secretion in medium and large follicles of Group 2 goats. However, neither FSH nor LH influenced oxytocin secretion significantly when added to the culture media of cells isolated before or after the LH surge.

Table 1. Oxytocin accumulation (ng/mg protein) during 24-h cultures of granulosa cells collected $6-12 \mathrm{~h}$ after the estimated time of the LH surge in oestrus-synchronized goats

\begin{tabular}{lcccc}
\hline & \multicolumn{4}{c}{ In-vitro treatment } \\
\cline { 2 - 5 } $\begin{array}{l}\text { Follicle } \\
\text { size }\end{array}$ & Control & $\begin{array}{c}\text { FSH } \\
(0 \cdot 1 \mu \mathrm{g} / \mathrm{ml})\end{array}$ & $\begin{array}{c}\mathrm{LH} \\
(1 \mu \mathrm{g} / \mathrm{ml})\end{array}$ & $\begin{array}{c}\text { PGE-2 } \\
(1 \mu \mathrm{g} / \mathrm{ml})\end{array}$ \\
\hline Small & $\mathrm{ND}$ & $\mathrm{ND}$ & $\mathrm{ND}$ & $\mathrm{ND}$ \\
Medium & $8 \cdot 6 \pm 0 \cdot 6^{\mathrm{a}}$ & $10 \cdot 1 \pm 1 \cdot 0^{\mathrm{a}}$ & $9 \cdot 3 \pm 1 \cdot 1^{\mathrm{a}}$ & $11 \cdot 7 \pm 0 \cdot 5^{\mathrm{b}}$ \\
Large & $7 \cdot 4 \pm 1 \cdot 0^{\mathrm{a}}$ & $7 \cdot 3 \pm 0 \cdot 6^{\mathrm{a}}$ & $7 \cdot 6 \pm 0 \cdot 8^{\mathrm{a}}$ & $9 \cdot 4 \pm 0 \cdot 4^{\mathrm{b}}$ \\
\hline
\end{tabular}

Tabular values are means \pm s.e.m. of quadruplicate cultures of pooled granulosa cells. The experiment was carried out in 2 replicates of 8 goats per treatment per replicate. Values presented in the table are from the second replicate, the results of which were qualitatively similar to those from the first replicate.

$\mathrm{ND}=$ non-detectable (below the assay limit of detection of $<0.1 \mathrm{ng} / \mathrm{mg}$ protein per $24 \mathrm{~h}$ culture). All values for oxytocin accumulation by cultured cells isolated before the LH surge were undetectable.

Values with different superscripts within the same follicle size class are significantly different $(P<0 \cdot 05)$. Cells from medium-sized follicles produced significantly more oxytocin than did cells from large follicles, over all in-vitro treatments $(P<0 \cdot 05)$.

Progesterone. Progesterone production was detected in culture media of granulosa cells from all sizes of follicle from goats of Groups 1 and 2 (Table 2). Irrespective of hormone treatment in vitro, cells from large and medium follicles secreted more progesterone than did cells from small follicles, and cells from medium and large follicles obtained after the LH surge (Group 2) produced significantly more progesterone during $24 \mathrm{~h}$ culture than did those isolated before the LH surge (Group 1). There was no difference in progesterone production between small follicles of Groups 1 and 2 . None of the in-vitro hormone treatments significantly affected the production of progesterone under the culture conditions used.

\section{Hormone production by granulosa cells from FSH-treated goats}

In Exp. II, GnRH was injected to induce an LH surge and thus permit more accurate assessment of the responses in relation to endogenous $\mathrm{LH}$ secretion. $\mathrm{LH}$ concentrations in jugular blood were monitored by sampling of all animals for the first $4 \mathrm{~h}$ after $\mathrm{GnRH}$ injection. Elevated plasma LH was observed in 4 of the $22 \mathrm{GnRH}$-treated goats $30 \mathrm{~h}$ after progestagen sponge withdrawal, i.e. before the injection of GnRH. Of the remaining 18 females receiving GnRH, LH became significantly elevated in 15 animals by the blood sample at 1 or $2 \mathrm{~h}$ after GnRH injections. No LH surges were observed within $4 \mathrm{~h}$ of $\mathrm{GnRH}$ in the 3 remaining animals; therefore, these animals were 
Table 2. Progesterone accumulation (ng/mg protein) during 24-h culture of granulosa cells collected before (Group 1) or 6-12 h after (Group 2) the estimated time of the LH surge in oestrus-synchronized goats

\begin{tabular}{|c|c|c|c|c|c|}
\hline \multirow[b]{2}{*}{ Group } & \multirow{2}{*}{$\begin{array}{l}\text { Follicle } \\
\text { size }\end{array}$} & \multicolumn{4}{|c|}{ In-vitro treatment } \\
\hline & & Control & FSH & LH & PGE-2 \\
\hline $\begin{array}{l}1 \text { (before LH } \\
\text { surge) }\end{array}$ & $\begin{array}{l}\text { Small } \\
\text { Medium } \\
\text { Large }\end{array}$ & $\begin{array}{l}12 \cdot 3 \pm 1 \cdot 5 \\
14 \cdot 2 \pm 4 \cdot 6 \\
15 \cdot 2 \pm 1 \cdot 1\end{array}$ & $\begin{array}{l}13.4 \pm 1.1 \\
10.8 \pm 2.6 \\
15.0 \pm 1.6\end{array}$ & $\begin{array}{l}15 \cdot 2 \pm 2 \cdot 3 \\
11 \cdot 1 \pm 0 \cdot 8 \\
12.0 \pm 1 \cdot 6\end{array}$ & $\begin{array}{l}11.9 \pm 2.9 \\
12.8 \pm 4.2 \\
12.9 \pm 2.0\end{array}$ \\
\hline $\begin{array}{l}2 \text { (after LH } \\
\text { surge) }\end{array}$ & $\begin{array}{l}\text { Small } \\
\text { Medium } \\
\text { Large }\end{array}$ & $\begin{array}{r}14.9 \pm \mathrm{I} \cdot 6 \\
115.5 \pm 10.3 \\
208.8 \pm 17.5\end{array}$ & $\begin{array}{r}16.5 \pm 2.2 \\
82.8 \pm 18.3 \\
199.2 \pm 8.6\end{array}$ & $\begin{array}{r}13 \cdot 9 \pm 2 \cdot 0 \\
91 \cdot 4 \pm 1 \cdot 1 \\
224 \cdot 8 \pm 14 \cdot 9\end{array}$ & $\begin{array}{r}14 \cdot 6 \pm 1 \cdot 8 \\
64 \cdot 6 \pm 7 \cdot 1 \\
168 \cdot 4 \pm 11 \cdot 0\end{array}$ \\
\hline
\end{tabular}

Values are means \pm s.e.m. of quadruplicate cultures of pooled granulosa cells. The experiment was carried out in 2 replicates of 8 goats per treatment per replicate. The results of the two replicates did not differ significantly $(P<0.05)$; those presented in the table are for the second replicate.

Analysis of variance indicated no significant differences due to in-vitro treatment or to follicle size within group 1 (i.e. isolated before the LH surge). Values for medium and large follicles after the LH surge were significantly greater $(P<0.01)$ than for small follicles after the LH surge (Group 2$)$ and for all follicle sizes before the LH surge (Group I).

excluded from the results. Mean peak $\mathrm{LH}$ values and mean times of observation of peak $\mathrm{LH}$ for animals receiving GnRH are presented in Table 3. Although the magnitude of the peak values differed greatly among animals, possibly due to missing maximal values as a result of sampling only once per hour, neither the times of occurrence nor magnitudes of observed peak values differed significantly between the 3 groups.

Table 3. Time and mean value of maximum $\mathrm{LH}(\mathrm{ng} / \mathrm{ml}$ plasma) in goats after a bolus injection of GnRH (50 mg)

\begin{tabular}{lcccc}
\hline $\begin{array}{l}\text { Time of } \\
\text { ovariectomy } \\
\text { (h after GnRH) }\end{array}$ & $\begin{array}{c}\text { Treated with } \\
\text { GnRH }\end{array}$ & $\begin{array}{c}\text { Exhibiting } \\
\text { LH surge }\end{array}$ & $\begin{array}{c}\text { Mean } \pm \text { s.e. } \\
\text { time of LH peak } \\
\text { (h after GnRH) }\end{array}$ & $\begin{array}{c}\text { Peak LH* } \\
\text { value } \\
\text { (ng/ml) }\end{array}$ \\
\hline 0 & 6 & - & - & $5 \cdot 8 \pm 0 \cdot 5^{*}$ \\
6 & 8 & 7 & $2 \cdot 4 \pm 1 \cdot 4$ & $87 \cdot 2 \pm 34 \cdot 6$ \\
12 & 6 & 6 & $1 \cdot 7 \pm 1 \cdot 0$ & $69 \cdot 9 \pm 29 \cdot 3$ \\
18 & 8 & 5 & $2 \cdot 6 \pm 0.5$ & $86.5 \pm 50 \cdot 4$ \\
\hline
\end{tabular}

Values are mean \pm s.e.m. expressed in terms of the NIH-LH-S24 reference preparation which has a specific LH activity $2 \cdot 3 \times$ that of NIH-LH-SI.

* Mean basal $\mathbf{L H}$ value (before GnRH-induced LH surge).

Increases in oxytocin and progesterone secretion by granulosa cells in vitro occurred in parallel relative to the synchronized endogenous LH surge, with significant increases $(P<0.05)$ in secretion of both hormones being evident within $6-12 \mathrm{~h}$ of the LH surge (Table 4). The magnitude of oxytocin secretion, $3.53 \mathrm{ng} / \mathrm{mg}$ protein per $24 \mathrm{~h}$ culture (Group 4), was similar to that observed in the first study. The magnitude of progesterone secretion in vitro was lower than observed in Exp. I (Table 2 vs Table 4), in which PMSG rather than FSH was the gonadotrophin used in the oestrussynchronization regimen. Oestradiol-17\% production in vitro in cells cultured in the presence of androstenedione as an aromatizable substrate decreased significantly $(P<0.05)$ in Group 4 , by $18 \mathrm{~h}$ after the LH surge (Table 4).

Concentrations of oxytocin and progesterone determined in ovarian venous plasma, sampled at the time of ovariectomy, followed a pattern similar to that observed for production of the hormones by granulosa cells cultured for $24 \mathrm{~h}$ (Table 5). Similar trends were observed for oxytocin 
Table 4. Mean concentration of hormones in media ( $\mathrm{ng} / \mathrm{mg}$ protein) after 24 -h culture of granulosa cells collected at various times after $\mathrm{GnRH}$ treatment

\begin{tabular}{lcccc}
\hline \multirow{2}{*}{$\begin{array}{l}\text { Time of } \\
\text { ovariectomy } \\
\text { (h after GnRH) }\end{array}$} & Oxytocin & Progesterone & $\begin{array}{c}\text { Without } \\
\text { androstenedione }\end{array}$ & $\begin{array}{c}\text { With } \\
\text { androstenedione }\end{array}$ \\
\hline 0 & $0 \cdot 10 \pm 0 \cdot 09^{\mathrm{a}}$ & $3.43 \pm 1 \cdot 81^{\mathrm{a}}$ & $0 \cdot 61 \pm 0 \cdot 31^{\mathrm{a}}$ & $31 \cdot 3 \pm 17 \cdot 5^{\mathrm{a}}$ \\
6 & $0 \cdot 08 \pm 0 \cdot 07^{\mathrm{a}}$ & $5 \cdot 25 \pm 2 \cdot 48^{\mathrm{a}}$ & $0 \cdot 73 \pm 0 \cdot 27^{\mathrm{a}}$ & $37 \cdot 4 \pm 14 \cdot 2^{\mathrm{a}}$ \\
12 & $1 \cdot 35 \pm 0 \cdot 52^{\mathrm{b}}$ & $35 \cdot 12 \pm 15 \cdot 63^{\mathrm{b}}$ & $0 \cdot 23 \pm 0 \cdot 04^{\mathrm{a}}$ & $34 \cdot 6 \pm 5 \cdot 0^{\mathrm{a}}$ \\
18 & $3 \cdot 51 \pm 1 \cdot 19^{\mathrm{b}}$ & $46.88 \pm 17 \cdot 37^{\mathrm{b}}$ & $0 \cdot 22 \pm 0 \cdot 08^{\mathrm{a}}$ & $7 \cdot 4 \pm 4 \cdot 6^{\mathrm{b}}$ \\
Intra-assay & $0.743 \%$ & $2 \cdot 52 \%$ & $0.978 \%$ & \\
CV & & & \\
\hline
\end{tabular}

Values are mean \pm s.e.m. for 5-7 replicate goats per granulosa cell collection time.

Values with different superscripts, within columns, are significantly different $(P<0.05)$.

concentrations in jugular vein plasma and follicular fluid sampled at the respective times after ovariectomy. Pooled correlation coefficients of the mean oxytocin concentrations at times of ovariectomy indicated significant correlation of ovarian vein concentration with follicular fluid $(0.94$, $P<0.05)$ and jugular vein concentrations $(0.63, P<0.05)$, but not with oxytocin production by cultured granulosa cells $(0 \cdot 10)$. Oxytocin production by cultured granulosa cells also had low correlation values with jugular vein $(0.39)$ and follicular fluid $(0.13)$ concentrations. There was a significant positive regression of mean oxytocin concentrations produced by cultured granulosa cells and time of ovariectomy.

Table 5. Mean concentrations of oxytocin and progesterone in jugular and ovarian venous plasma and follicular fluid from goats at sequential times after the synchronized endogenous gonadotrophin (LH) surge

\begin{tabular}{|c|c|c|c|c|c|}
\hline \multirow[b]{2}{*}{ Hormone } & \multirow{2}{*}{$\begin{array}{c}\text { Time } \\
\text { (h after } \\
\text { GnRH) }\end{array}$} & \multirow[b]{2}{*}{$\begin{array}{l}\text { No. of } \\
\text { goats }\end{array}$} & \multicolumn{3}{|c|}{ Hormone concentration in: } \\
\hline & & & $\begin{array}{l}\text { Jugular } \\
\text { vein }\end{array}$ & $\begin{array}{c}\text { Ovarian } \\
\text { vein }\end{array}$ & $\begin{array}{l}\text { Follicular } \\
\text { fluid }\end{array}$ \\
\hline $\begin{array}{l}\text { Oxytocin } \\
(\mathrm{pg} / \mathrm{ml})\end{array}$ & $\begin{array}{r}0 \\
6 \\
12 \\
18\end{array}$ & $\begin{array}{l}4 \\
7 \\
5 \\
5\end{array}$ & $\begin{array}{l}0.22 \pm 0.08 \\
0.42 \pm 0.06 \\
0.16 \pm 0.10 \\
0.29 \pm 0.12\end{array}$ & $\begin{array}{l}0.44 \pm 0.23 \\
2.45 \pm 0.39 \\
1.56 \pm 0.32 \\
2 \cdot 16 \pm 0.47\end{array}$ & $\begin{array}{r}67 \cdot 2 \pm 3 \cdot 3 \\
155 \cdot 3 \pm 3 \cdot 0 \\
265 \cdot 5 \pm 3 \cdot 2 \\
371 \cdot 8 \pm 2 \cdot 5\end{array}$ \\
\hline $\begin{array}{l}\text { Progesterone } \\
(\mathrm{ng} / \mathrm{ml})\end{array}$ & $\begin{array}{r}0 \\
6 \\
12 \\
18\end{array}$ & $\begin{array}{l}4 \\
7 \\
5 \\
5\end{array}$ & $\begin{array}{c}0.14 \pm 0.33 \\
<0.01 \\
0.09 \pm 0.37 \\
0.08 \pm 0.10\end{array}$ & $\begin{array}{l}0.22 \pm 0.11 \\
3.71 \pm 0.23 \\
3.80 \pm 0.35 \\
4.74 \pm 0.37\end{array}$ & $\begin{array}{l}\text { N.A. } \\
\text { N.A. } \\
\text { N.A. } \\
\text { N.A. }\end{array}$ \\
\hline
\end{tabular}

N.A., not assayed.

\section{Discussion}

It is evident from the results of this study that granulosa cells of large and medium follicles are capable of synthesizing substantial quantities of oxytocin in vitro, but only after exposure to the preovulatory gonadotrophin surge. These results are in agreement with the reports of in-vitro granulosa cell oxytocin secretion and immunocytochemical localization in the sheep follicle at around the time of the LH surge (Wathes et al., 1986), and of the presence of cyclic elevations in mRNA for oxytocin in follicular cell wall at the time of ovulation in the cow (Ivell et al., 1985). 
Granulosa cells begin to luteinize soon after the LH surge (Moor, 1977) and then become large luteal cells shortly after ovulation (Alila \& Hansel, 1984). Rodgers et al. (1983) clearly demonstrated that the large luteal cells of sheep contain oxytocin and are capable of synthesizing oxytocin in vitro, whereas small luteal cells (theca derived) appear neither to contain oxytocin nor to be capable of synthesizing it in vitro. In the present studies, granulosa cells of large and medium follicles obtained just before the expected LH surge were not able to synthesize appreciable amounts of oxytocin in vitro. However, it seems likely that the mechanisms that initiate oxytocin synthesis and secretion are not solely due to exposure to increased concentrations of LH or FSH.

Neither exogenous LH $(1.0 \mu \mathrm{g} / \mathrm{nl})$ nor FSH $(0 \cdot 1 \mu \mathrm{g} / \mathrm{ml})$, when added in vitro alone, at the single concentrations used, was able to stimulate the granulosa cells to secrete oxytocin regardless of whether the cells were obtained before or after the endogenous gonadotrophin surge. This observation is in contrast to the report that somewhat lower doses of FSH and LH stimulated oxytocin secretion by bovine granulosa cells during extended culture periods of $48 \mathrm{~h}$ and $120 \mathrm{~h}$ (Schams, 1987). The difference may be due to differences in species or in dose of gonadotrophin used, or to the longer periods of culture used in the latter study. The results suggest that a longer period is required for in-vitro $v s$ in-vivo induction of oxytocin synthesis by gonadotrophins. The short interval between the LH surge and elevation of oxytocin secretion in vivo (3-6 h) (present study) in contrast to the time for significantly increased secretion in vitro (48-120 h) (Schams, 1987) suggests either that culture conditions are suboptimal for expression of this action of $\mathrm{LH}$, or that a factor or factors other than gonadotrophins, e.g. oestradiol, may be involved in priming of the preovulatory follicle to respond rapidly to the LH surge. It is well documented for many species, including the goat (Chemineau et al., 1982; Armstrong et al., 1983a), that there is a large increase in oestradiol before and at the time of the LH surge.

There was a parallelism between oxytocin and progesterone production in vitro by granulosa cells of follicles collected both before and after the gonadotrophin surge. This parallel increase and decrease of both hormones has been reported in numerous studies in which plasma oxytocin and progesterone have been measured during the oestrous cycle (goat: Roberts, 1971; sheep: Sheldrick \& Flint, 1981; cattle: Schams, 1983). After the LH surge, but before ovulation, the steroidogenic activity of granulosa cells in preovulatory sheep follicles rapidly changed from oestradiol synthesis to predominantly progesterone synthesis (Murdoch \& Dunn, 1982), possibly due to a loss in androgen aromatizing activity (Henderson \& Moon, 1979).

PGE-2 was the only treatment that was capable of affecting the production of oxytocin significantly when added in vitro to cultured granulosa cells. It is not clear whether this is related to the in-vivo findings of Flint \& Sheldrick (1982) that exogenous PGE-2 stimulated the release of oxytocin from the corpus luteum of sheep. In the latter studies, PGF-2 $\alpha$ was also effective although it failed to stimulate the production of oxytocin in the present study. It is possible that a dose higher or lower than the one used or a longer culture period is required to elicit a response in vitro. It is also possible that luteinizing granulosa cells are not responsive to PGF-2 $\alpha$; in vivo, goat corpora lutea do not become responsive to the luteolytic administration of PGF- $2 \alpha$ until about Day 4 after ovulation (Bosu et al., 1978). Moreover, PGE-2 concentration increases in the follicular fluid and follicular tissue after the LH surge in sheep (Murdoch \& Dunn, 1982). It is therefore possible that PGE-2 may be involved in the increase in secretion of oxytocin from granulosa cells in vivo following the LH surge in the goat.

The results of the time-course study (Exp. II) support the conclusion that goat granulosa cells acquire the ability to secrete oxytocin within $6-12 \mathrm{~h}$ after exposure to the endogenous surge of gonadotrophin. Ability of granulosa cells to secrete oxytocin appears to occur in parallel with the enhanced ability of these cells to secrete progesterone in vitro, although the rate of secretion of oxytocin is increased 100 -fold compared to 10 -fold for progesterone within the same 6-h period. The apparent decrease in aromatase enzyme (oestrogen secretion) activity occurs later (i.e. $18 \mathrm{~h}$ ) than the observed increases in oxytocin and progesterone secretion which reach statistical significance $(P<0.05)$ within $6-12 \mathrm{~h}$ after the endogenous gonadotrophin $(\mathrm{LH})$ surge. The somewhat 
lower magnitudes of oxytocin and progesterone secretion in vitro in Exp. II than in Exp. I may indicate a more gradual development of the luteinization of follicles following superovulation with FSH, as used in Exp. II, than following use of PMSG, a gonadotrophin preparation with both FSH and LH activities (Papkoff, 1974).

The dosage of PMSG selected for Exp. I (400 i.u./single s.c. injection considered to be a nonsuperovulating dose) and the dosage of FSH selected for Exp. II (13.5 mg total dose, a modified superovulatory dose) are somewhat lower than the doses used in previous reports of endocrine responses in superovulated goats (Armstrong et al., 1983a). In the latter study, doses of 1000 i.u. PMSG and $18 \mathrm{mg}$ FSH resulted in mean number of ovulations of $10 \cdot 5 \pm 1.5$ and $17 \cdot 6 \pm 5 \cdot 5$, respectively, i.e. considerably greater than the average 2-3 expected for normal mixed-breed goats (Armstrong et al., 1983b). A significant proportion of goats superovulated with 1000 i.u. PMSG in that study had corpus luteum abnormalities as indicated by a high incidence of premature luteal failure. The lower doses of PMSG and FSH used in the present studies were selected as doses which would produce considerably more moderate degrees of superovulation, and therefore would presumably be less likely to produce such luteal abnormalities.

Previous studies in which oxytocin was measured in systemic (jugular vein) blood have provided evidence of oxytocin release in a pulsatile pattern throughout the oestrous cycle of ewes (Wathes et al., 1986) and cows (Walters \& Schallenberger, 1984; Walters et al., 1984). An episodic release pattern would indicate that a single plasma sample, as taken at the time of ovariectomy in the present experiments, does not accurately represent secretory capacity and, therefore, as was seen in the present experiment, one might not expect a high correlation between plasma concentrations and in-vitro secretion by cultured granulosa cells from selected follicles.

The physiological significance of follicular oxytocin, both within the ovary and in the adjacent reproductive tract, immediately before ovulation has not been precisely established. However, the close temporal relationship between production of oxytocin and progesterone in granulosa cells following the endogenous gonadotrophin surge suggested that they may both be considered as parts of the luteinization process, induced by the LH surge, and preceding other biochemical (e.g. reduction in aromatase activity) and morphological changes in the granulosa cells.

We thank Mr Gordon Young and Mr Gerald Barbe for skilled technical assistance; Dr D. K. Pomerantz for laboratory facilities (LH assays); Mr V. Pitelka for help with the LH assays; Dr D. Schams and Dr G. D. Niswender for generous donations of antisera for assay of oxytocin and $\mathrm{LH}$, respectively; and Mrs Nancy Wilson for typing the manuscript.

The research was supported by Medical Research Council of Canada. D.T.A. is a career investigator of the Medical Research Council of Canada.

\section{References}

Alila, H.W. \& Hansel, W. (1984) Origin of different cell types in the bovine corpus luteum as characterized by specific monoclonal antibodies. Biol. Reprod. 31, 1015-1025.

Armstrong, D.T. \& Hansel, W. (1959) Alteration of the bovine estrous cycle with oxytocin. J. Dairy Sci. 42, 533-542.

Armstrong, D.T., Pfitzner, A.P., Warnes, G.M., Ralph, M.M. \& Seamark, R.F. (1983a) Endocrine responses of goats after induction of superovulation with PMSG and FSH. J. Reprod. Fert. 67, 395-401.

Armstrong, D.T., Pfitzner, A.P., Warnes, G.M. \& Seamark, R.F. (1983b) Superovulation treatments and embryo transfer in Angora goats. J. Reprod. Fert. 67, 403-410.
Bosu, W.T.K., Serna, J.A. \& Barker, C.A.W. (1978) Peripheral plasma levels of progesterone in goats treated with fluorogestone acetate and prostaglandin $F_{2 a}$ during the oestrous cycle. Theriogenology 9, 371-390.

Chemineau, P., Gauthier, D., Poirier, J.C. \& Saumande, J. (1982) Plasma levels of LH, FSH, prolactin, oestradiol-17 $\beta$ and progesterone during natural and induced oestrus in the dairy goat. Theriogenology 17, 313-323.

Cooke, R.G. \& Knifton, A. (1981) Oxytocin-induced oestrus in the goat. Theriogenology 16, 95-97.

Daniel, S.A.J. \& Armstrong, D.T. (1984) Site of action of androgens in follicle-stimulating hormone-induced aromatase activity in cultured rat granulosa cells. Endocrinology 119, 1975-1982. 
Flint, A.P.F. \& Sheldrick, E.L. (1982) Ovarian secretion of oxytocin is stimulated by prostaglandin. Nature, Lond. 297, 587-588.

Flint, A.P.F. \& Sheldrick, E.L. (1983) Evidence for a systemic role for ovarian oxytocin in luteal regression in sheep. J. Reprod. Fert. 67, 215-225.

Geenen, V., Legros, J.J., Hazee-Hagelstein, M.T., LouisKohn, F., Lecomte-Verna, M.J., Demoulin, A. \& Franchimont, P. (1985) Release of immunoreactive oxytocin and neurophysin by cultured luteinizing bovine granulosa cells. Acta endocr., Copenh. 110, 263-270.

Henderson, K.M. \& Moon, Y.S. (1979) Luteinization of bovine granulosa cells and corpus luteum formation associated with loss of androgen aromatizing abilities. J. Reprod. Fert. 56, 89-97.

Ivell, R., Brackett, K.H., Fields, M.J. \& Richter, D. (1985) Ovulation triggers oxytocin gene expression in the bovine ovary. FEBS Lett. 190, 263-267.

Jungclas, B. \& Luck, M.R. (1986) Evidence for granulosa-theca interaction in the secretion of oxytocin by bovine ovarian tissue. J. Endocr. 109, R1-R4.

Kruip, Th.A.M., Vullings, H.G.B., Schams, D., Toms, J. \& Klarenbeck, A. (1985) Immunocytochemical demonstration of oxytocin in bovine ovarian tissues. Acta endocr., Copenh. 109, 537-542.

Leung, P.C.K. \& Armstrong, D.T. (1979) Estrogen treatment of immature rats inhibits ovarian androgen production in vitro. Endocrinology 104, 1411-1417.

Lischinsky, A. \& Armstrong, D.T. (1983) Granulosa cell stimulation of thecal androgen synthesis. Can. J. Physiol. Pharmacol. 61, 472-477.

Lowry, O.H., Rosebrough, N.J., Farr, A.L. \& Randall, R.J. (1951) Protein measurement with the Folin phenol reagent. J. biol. Chem. 193, 265-275.

Moor, R.M. (1977) Sites of steroid production in ovine Graafian follicles in culture. J. Endocr. 73, 143-150.

Murdoch, W.J. \& Dunn, T.G. (1982) Alterations in follicular steroid hormones during the preovulatory period in the ewe. Biol. Reprod. 27, 300-307.

Niswender, G., Reichert, L.E., Midgley, A.R.\& Nalbandov, A.V. (1969) Radioimmunoassay for bovine and ovine luteinizing hormone. Endocrinology 84, 1166-1173.

Ott, I. \& Scott, J.C. (1910a) The action of infundibulum upon the mammary secretion. Proc. Soc. exp. Biol. Med. 8, 48-49.

Ott, I. \& Scott, J.C. (1910b) The galactagogue action of the thymus and corpus luteum. Proc. Soc. exp. Biol. Med. 8, 49, abstr.

Papkoff, H. (1974) Chemical and biological properties of the subunits of pregnant mare serum gonadotrophin. Biochem. Biophys. Res. Commun. 58, 397-404.
Roberts, J.S. (1971) Seasonal variations in the reflexive release of oxytocin and in the effect of oestradiol on the reflex in goats. Endocrinology 89, 1029-1033.

Rodgers, R.J., O'Shea, J.D., Findlay, J.K., Flint, A.P.F. \& Sheldrick, E.L. (1983) Large luteal cells the source of luteal oxytocin in the sheep. Endocrinology 113, 2302-2304.

Schams, D. (1983) Oxytocin determination by radioimmunoassay. III. Improvement to subpicogram sensitivity and application to blood levels in cyclic cattle. Acta endocr., Copenh. 103, 180-183.

Schams, D. (1987) Luteal peptides and intercellular communication. J. Reprod. Fert., Suppl. 34, 87-99.

Schams, D., Schmidt-Polex, B. \& Kruse, V. (1979) Oxytocin determination by radioimmunoassay in cattle. Acta endocr., Copenh. 92, 258-270.

Schams, D., Kruip, Th.A.M. \& Knoll, R. (1985) Oxytocin determination in steroid producing tissues and in vitro production in ovarian follicles. Acta endocr., Copenh. 109, 530-536.

Sheldrick, E.L. \& Flint, A.P.F. (1981) Circulating concentrations of oxytocin during the estrous cycle and early pregnancy in the sheep. Prostaglandins 22, 631-636.

Sheldrick, E.L. \& Flint, A.P.F. (1983) Luteal concentration of oxytocin decline during early pregnancy in the ewe. J. Reprod. Fert. 68, 477-480.

Sheldrick, E.L. \& Flint, A.P.F. (1984) Ovarian oxytocin and luteal function in the early pregnant sheep. Anim. Reprod. Sci. 7, 101-113.

Steel, R.G.D. \& Torrie, J.H. (1960) Principles and Procedures of Statistics. McGraw-Hill, New York.

Walters, D.L. \& Schallenberger, E. (1984) Pulsatile secretion of gonadotrophins, ovarian steroids and ovarian oxytocin during the periovulatory phase of the oestrous cycle of the cow. J. Reprod. Fert. 71, 503-512.

Walters, D.L., Schams, D. \& Schallenberger, E. (1984) Pulsatile secretion of gonadotrophins, ovarian steroids and ovarian oxytocin during the luteal phase of the oestrous cycle in the cow. J. Reprod. Fert. 71, $479-491$.

Wathes, D.C. (1984) Possible actions of gonadal oxytocin and vasopressin. J. Reprod. Fert. 71, 315-345.

Wathes, D.C. \& Swann, R.W. (1982) Is oxytocin an ovarian hormone? Nature, Lond. 297, 225-227.

Wathes, D.C., Guldenaar, S.E.F., Swann, R.W., Webb, R., Porter, D.G. \& Pickering, B.T. (1986) A combined radioimmunoassay and immunocytochemical study of ovarian oxytocin production during the periovulatory period in the ewe. J. Reprod. Fert. 78, 167-183.

Received 22 January 1989 